\title{
FAILURE OF LOW MOLECULAR WEIGHT DEXTRAN INFUSIONS IN SCLERODERMA
}

\author{
BY
}

\author{
J. A. KIRK AND A. ST. J. DIXON \\ From the Royal National Hospital for Rheumatic Diseases, Bath
}

Of the many treatments used in scleroderma (progressive systemic sclerosis), none has so far been shown to alter the fundamental course of the disease (see review Bywaters and Scott, 1965).

Although corticosteroids may give symptomatic benefit in the early stages (Rodnan, Black, Bollet, and Bunim, 1956), prolonged therapy is unrewarding (Zion, Goldberg, and Suzman, 1955). Several other promising treatments such as relaxin (Jefferis and Dixon, 1962) and epsilon-aminocaproic acid (Hall and Scott, 1966) have not stood the test of a controlled study.

Since their introduction in the late 1940s, dextrans have come to occupy an important place in clinical medicine. Low molecular weight dextran increases peripheral circulation by reducing both blood viscosity and intravascular red cell aggregation (Gelin and Zederfeldt, 1960) and an extensive literature has accumulated on its use in peripheral vascular disorders (Powley, 1964).

Digital ischaemia is a prominent feature of scleroderma, yet scanty information is available on the use of low molecular weight dextran in this disease. Holti (1965) convincingly demonstrated that intermittent infusions temporarily improved digital ischaemic phenomena in ten out of twelve patients with scleroderma and noted that "these patients claimed to be remarkably better in themselves with an increased exercise tolerance and softening of their indurated facial skin".

Using Holti's technique, Denis (1967) found a similar circulatory improvement in five of seven patients. In addition joint stiffness improved in some patients, dysphagia lessened in one, and facial telangiectasis in another. Kantor (1966) treated five scleroderma patients with single dextran infusions; in one the skin texture "improved about 50 per cent.", and in the remainder "a decided softening of the acral skin" was noted.

Scleroderma is not primarily a vascular disease. Although dextran may temporarily improve the digital circulation, the important question of whether the course of progressive systemic sclerosis itself is intluenced needed to be resolved in a carefully controlled clinical evaluation.

\section{Material and Methods}

Six patients with scleroderma were selected for this study, the duration of disease ranging from early (6 months) to late (29 years), and the severity from mild and static to rapidly progressive (Table I, overleaf). All six showed clinical evidence of digital ischaemia including pulp pitting and atrophy (Fig. 1) and painful digital ulceration.

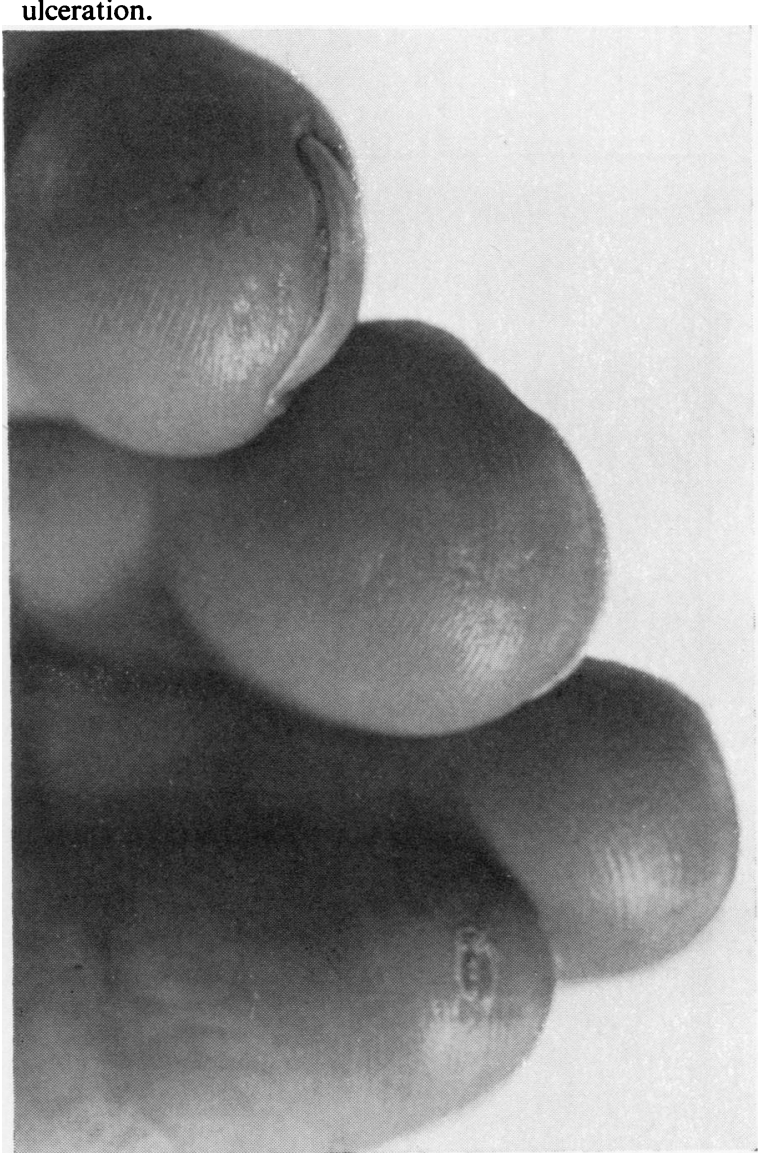

Fig. 1.-Pulp pitting and atrophy. 
TABLE I

DETAILS OF PATIENTS

\begin{tabular}{|c|c|c|c|c|c|}
\hline $\begin{array}{l}\text { Case } \\
\text { No. }\end{array}$ & $\begin{array}{c}\text { Age } \\
\text { (yrs) }\end{array}$ & Sex & Type of Scleroderma & Details & Previous Treatments \\
\hline 1 & 44 & Female & Advanced progressive & $\begin{array}{l}\text { Raynaud's phenomenon } 16 \text { yrs } \\
\text { Scleroderma fingers } 4 \text { yrs, face and trunk } \\
3 \text { yrs } \\
\text { Diarrhoea } 4 \text { yrs } \\
\text { Facial telangiectasis } \\
\text { MCP erosions }\end{array}$ & $\begin{array}{l}\text { Triidothyronine and decaser- } \\
\text { pasyl }\end{array}$ \\
\hline 2 & 56 & Female & $\begin{array}{l}\text { "CRST syndrome" (calcino- } \\
\text { sis, Raynaud's phenome- } \\
\text { non, sclerodactyly, telan- } \\
\text { giectasis) }\end{array}$ & $\begin{array}{l}\text { Raynaud's phenomenon } 29 \text { yrs } \\
\text { Scleroderma hands } 28 \text { yrs } \\
\text { Painful digital ulcers, calcinosis with } \\
\text { ulcerating calcium plaques (Fig. 2) } \\
\text { Contractures knees, elbows } \\
\text { Widespread telangiectasis }\end{array}$ & $\begin{array}{l}\text { Corticosteroids } \\
\text { Versenate }\end{array}$ \\
\hline 3 & 40 & Female & Early mild "acrosclerosis" & $\begin{array}{l}\text { Raynaud's phenomenon } 4 \text { yrs } \\
\text { Scleroderma fingers } 4 \text { mths } \\
\text { Pulp necroses fingers (Fig. 1) }\end{array}$ & $\begin{array}{l}\text { Cervical, lumbar sympathec- } \\
\text { tomy } \\
\text { Triidothyronine and decaser- } \\
\text { pasyl }\end{array}$ \\
\hline 4 & 57 & Female & $\begin{array}{l}\text { Acute onset, rapidly progres- } \\
\text { sive }\end{array}$ & $\begin{array}{l}\text { Generalized scleroderma } 6 \text { mths } \\
\text { Contractures wrists, elbows, ankles, and } \\
\text { fingers (hand models, Fig. 4) }\end{array}$ & Corticosteroids \\
\hline 5 & 56 & Female & $\begin{array}{l}\text { Progressive, with generalized } \\
\text { oedema }\end{array}$ & $\begin{array}{l}\text { Scleroderma hands, face, and trunk, } 2 \text { yrs } \\
\text { Intradermal (Fig. 3) and subcutaneous } \\
\text { oedema } \\
\text { Prominent arthritis wrists, ankle } \\
\text { Oesophageal and small bowel involvement }\end{array}$ & $\begin{array}{l}\text { Triidothyronine and decaser- } \\
\text { pasyl } \\
\text { Vasodilators }\end{array}$ \\
\hline 6 & 56 & Female & $\begin{array}{l}\text { Steadily progressive genera- } \\
\text { lized }\end{array}$ & $\begin{array}{l}\text { Raynaud's phenomenon } 2 \text { yrs } \\
\text { Scleroderma hands } 1 \mathrm{yr} \text {, arms and face } \\
8 \mathrm{mths} \\
\text { Oesophageal and pulmonary involvement } \\
\text { E.C.G. abnormal intraventricular con- } \\
\text { duction }\end{array}$ & $\begin{array}{l}\text { Potaba } \\
\text { Corticosteroids } \\
\text { Triidothyronine and decaser- } \\
\text { pasyl }\end{array}$ \\
\hline
\end{tabular}


Calcinosis (Fig. 2), extensive telangiectasis, and visceral involvement (cardiac, pulmonary, oesophageal, and intestinal) were all represented. Widespread intradermal oedema which retained the examiner's fingerprint (Fig. 3) was a feature in one patient.

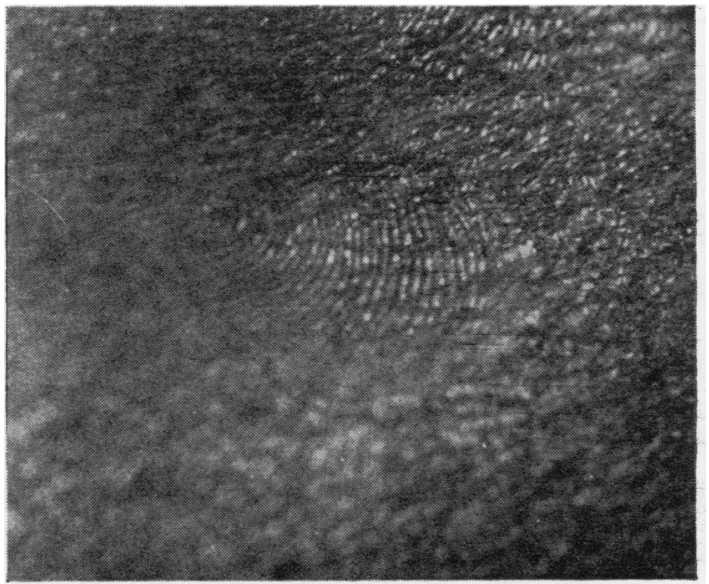

Fig. 3.-Finger-printing on patient's skin.

Intravenous infusions of low molecular weight dextran (10 per cent. $\mathrm{W} / \mathrm{V}$ in normal saline) were given according to the method of Holti (1965). Patients were admitted to hospital an average of four times at 3 to 5 week intervals to receive a continuous infusion of 21 . dextran given over 48 hours on each occasion.
After a preliminary study in four patients, two of these and two others were admitted to a trial in which each patient was given a course of either dextran or normal saline, the treatment being allocated in a double-blind fashion. In patients who received both substances, at least 3 months elapsed between courses.

\section{Assessment}

The effects of treatment were assessed before and a week after the course of infusions by the following methods:

(1) Detailed symptomatic enquiry.

(2) Hands: Grip strengths, jeweller's ring sizes, palm printing, or serial plaster models (Fig. 4) according to the degree of deformity.

(3) Photographic recording of skin ulceration, telangiectasis, facial appearances, etc.

(4) Joints and contractures: Ranges of movement, - assessment of pain and stiffness, serial joint radiographs.

(5) Digital blood flow: Changes in finger tip temperature using radiometer measurement of radiant heat emission during standardized reflex body warming.

(6) Serial chest radiograph, electrocardiograph, blood examination, and other investigations where appropriate.

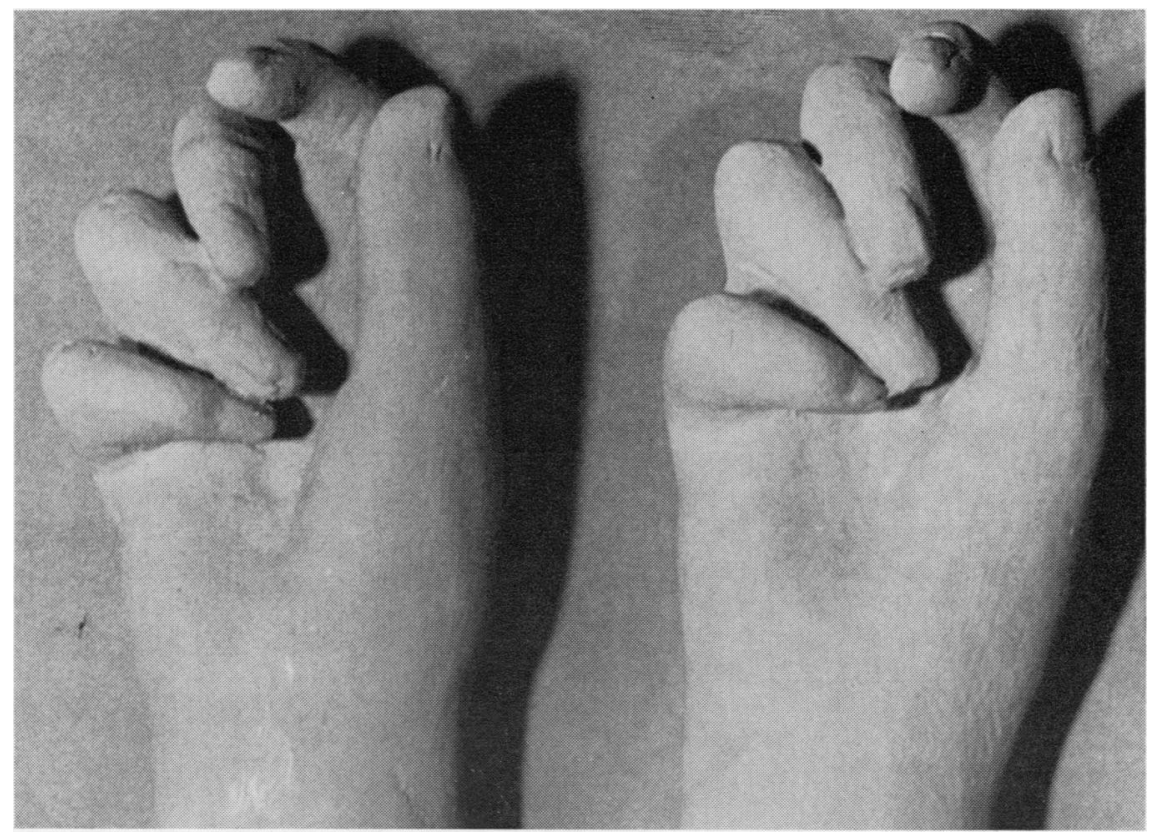

Fig. 4.-Plaster models showing degree of deformity before and after treatment. 


\section{Results}

Table II summarizes the results of treatment in the six patients. Patients $2,3,5$, and 6 received infusions the nature of which was unknown to them and the authors until after the final assessment. As a result of random allocation Patients 5 and 6 received courses of both dextran and saline. Five patients noted an increase in energy and sense of wellbeing with dextran, either after each infusion or as a result of the course. One of these, however, experienced the same subjective improvement with saline. Another volunteered that her hands felt looser and the skin softer for a few days after each dextran infusion, although the changes were not of a sufficient degree to be appreciated by observers.

The tendency to Raynaud's phenomenon and ischaemic finger pain or ulceration lessened with dextran in three of the four patients in whom this had been a major problem, but increased in the fourth. Measurement of augmented radiant heat emission from the finger tips frequently showed temperature differentials of greater than $0.5^{\circ} \mathrm{C}$. in adjacent digits in keeping with the clinical signs of peripheral vascular insufficiency and serial readings confirmed the patients' impression of increased finger warmth. On occasions the fingers were 3 observed to become warm and pink after each dex- $\square$

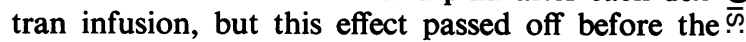
next infusion 3 to 5 weeks later except in Patient $1 \overrightarrow{\vec{*}}$ in whom benefit persisted over several winter months. Saline infusions did not influence the digital circulation in either of the two cases studied.

Photography confirmed that facial telangiectasis $\vec{\nabla}$ diminished in one patient but increased in another $\cong$ during the course of dextran infusions.

Visceral manifestations of systemic sclerosis were $\overrightarrow{0}$ not improved with the possible exception of Patient 1 whose intake of codeine to control diarrhoea was $\vec{\omega}$ halved during a course of dextran. However, at the same time, localized electrocardiographic $T$ wave $\overline{0}$ flattening first appeared, consistent with the develop- ${ }_{\infty}$ ment of sclerodermatous myocardial involvement. Patient 5 first developed dysphagia from radio- $\overrightarrow{0}$ logically-proven oesophageal scleroderma during a 웅 course of dextran infusions and this complaint $\rightarrow$ lessened considerably 4 months later while she was ${ }_{\widehat{N}}$ receiving saline. Weight loss from intestinal malabsorption in this patient progressed throughout the period of observation.

TABLE II

RESULT OF TREATMENT

\begin{tabular}{|c|c|c|c|c|c|}
\hline $\begin{array}{l}\text { Case } \\
\text { No. }\end{array}$ & Treatment & Subjective Changes & Objective Changes & Comments & Results \\
\hline 1 & Dextran & $\begin{array}{l}\text { More energy; fingers feel } \\
\text { warmer; Raynaud's crises } \\
\text { less frequent }\end{array}$ & $\begin{array}{l}\text { Facial contracture and telangiectasis worsened } \\
\text { E.C.G. localized T wave flattening developed } \\
\text { Diarrhoea lessened } \\
\text { Digital temperature improved } \\
\text { Ischaemic ulcers healing }\end{array}$ & $\begin{array}{l}\text { Migraine } \\
\text { Transient rash } \\
\text { Infusion } \\
\text { difficulties }\end{array}$ & $\begin{array}{l}\text { Prolonged improvement } \\
\text { in digital circulation } \\
\text { Scleroderma progressed }\end{array}$ \\
\hline 2 & Dextran & $\begin{array}{l}\text { Feels better; more energy; } \\
\text { joints less painful }\end{array}$ & $\begin{array}{l}\text { Hand function unimproved, further ulcerating } \\
\text { calcium plaques } \\
\text { Telangiectasis face lessened } \\
\text { One elbow increased } 10^{\circ} \text { in range } \\
\text { Fingers colder }\end{array}$ & & $\begin{array}{l}\text { Deterioration in digital } \\
\text { circulation } \\
\text { Scleroderma unchanged }\end{array}$ \\
\hline 3 & Dextran & $\begin{array}{l}\text { Each infusion, gave a 2- } \\
\text { week "boost" in energy; } \\
\text { ischaemic pain tempor- } \\
\text { arily lessened }\end{array}$ & $\begin{array}{l}\text { Digital temperature improved } \\
\text { Sclerodactyly unchanged }\end{array}$ & $\begin{array}{l}\text { Infusion } \\
\text { difficulties }\end{array}$ & $\begin{array}{l}\text { Temporary circulatory } \\
\text { improvement only }\end{array}$ \\
\hline 4 & Dextran & $\begin{array}{l}\text { Hands feel looser and skin } \\
\text { softer for a few days post- } \\
\text { infusion }\end{array}$ & $\begin{array}{l}\text { No change in hand deformity or digital } \\
\text { temperature }\end{array}$ & & No worthwhile benefit \\
\hline \multirow[t]{2}{*}{5} & Dextran & Feels better; more energy & $\begin{array}{l}\text { Dysphagia developed } \\
\text { Joint erosion progressed } \\
\text { Scleroderma increased in limbs, face, and } \\
\text { trunk } \\
\text { Tendon crepitus first appeared }\end{array}$ & & Disease progressed \\
\hline & Saline & Feels better; more energy & $\begin{array}{l}\text { Dysphagia improved } \\
\text { Weight loss continued (malabsorption) } \\
\text { Grip improved } 30 \text { per cent. but arthritis and } \\
\text { sclerodactyly progressed }\end{array}$ & & Disease progressed \\
\hline \multirow[t]{2}{*}{6} & Dextran & $\begin{array}{l}\text { Increased wellbeing; } \\
\text { ischaemic finger pain less }\end{array}$ & Steady progression of tissue stiffness & $\begin{array}{l}\text { Hypersensitivity } \\
\text { reaction } \\
\text { Infusion } \\
\text { difficulties }\end{array}$ & $\begin{array}{l}\text { Temporary circulatory } \\
\text { improvement } \\
\text { Scleroderma progressed }\end{array}$ \\
\hline & Saline & No change & $\begin{array}{l}\text { Facial scleroderma progressed } \\
\text { Axillary contractures lessened }\end{array}$ & $\begin{array}{l}\text { Infusion } \\
\text { difficulties }\end{array}$ & Scleroderma progressed \\
\hline
\end{tabular}


Sclerodermatous changes in the hands, limbs, face, and trunk either remained static or progressed during treatment with both dextran and saline and in no case did the course of the disease appear to be significantly influenced by these procedures. Patient 6 experienced a lessening of axillary contractures while her facial involvement steadily increased. At the conclusion of the study it emerged that the localized improvement coincided with saline infusions.

Practical difficulties emerged in giving repeated infusions to patients with tough skin and poor circulation. The problems of siting the needle in one patient precluded consideration of further therapy and in two others the difficulty of maintaining the infusion made them dread the next hospital admission. A solution was found in the use of infant scalp vein sets (Portex, 23 Guage) inserted into small superficial veins and held in place by a plaster of paris shell. This method is recommendded for similar procedures.

The dextran itself was not universally well tolerated by patients. A hypersensitivity reaction in the form of fever and generalized rash developed in one woman with a history of allergy to other agents. In another, migrainous attacks, to which she was otherwise infrequently subject, accompanied two out of five infusions and transient generalized pruritis with a fine macular rash occurred once although the causal relationship was not established with certainty.

\section{Discussion}

Dextrans are the polysaccharides formed by Leuconostoc Mesenteroides cultured in a sucrosecontaining medium (Ricketts, 1961). The British Pharmacopoeia contains three dextrans with average molecular weights 150,000 (Dextran 150 B.P.), 110,000 (Dextran 110 B.P.), and 40,000 (Dextran 40 B.P.).

The relative properties of dextrans are largely dependent on their molecular weight (Gronwall, 1957). Low molecular weight dextran increases blood flow in the microcirculation by means of a disaggregating effect on human erythrocytes (Gelin and Ingelman, 1961), a reduction in whole blood viscosity at low flow rates in excess of the effect of haemodilution (Gregersen, Peric, Usami, Chien, Chang, and Sinclair, 1963), and an increase in intravascular volume leading to increased venous return and cardiac output (Schenk, Delin, Domanig, Hahnloser, and Hoyt, 1964). The duration of action depends mainly on the renal threshold for dextran which is around molecular weight 50,000 .
In view of the established place of dextran in the treatment of peripheral vascular disorders, it is reasonable that this agent should be suggested for use in scleroderma in which a regular feature is digital ischaemia due to intimal thickening of the digital arteries and peripheral microthromboses. Previous reports (Holti, 1965; Denis, 1967) and our own experience confirm that peripheral tissue perfusion is enhanced in at least 50 per cent. of patients although the benefit is usually transient.

However, ischaemia accompanies but is not the cause of scleroderma and the improvement in circulation with dextran, although welcome, does not necessarily presage an improvement in the sclerodermatous involvement of tissues. Encouraging initial reports, such as that of Klein and Harris (1955) on the use of chelation with sodium versenate, have later proved to be disappointing in other treatments in cases of scleroderma, and the results of this study suggest that this will be so with dextran.

Therapeutic assessment in scleroderma is fraught with difficulties. Subjective responses may be influenced by the desire of both patient and physician to see improvement in a disease in which previous treatments have proved valueless. Temporary hydration of the tissues with resulting softening may follow dextran infusions and natural fluctuations of the disease can further confuse assessment. Furthermore, this is a dramatic form of treatment. It involves infusions and periods of confinement to bed in hospital. This may introduce placebo responses unrelated to the basic course of the disease.

The use of saline control infusions has illustrated these aspects. One patient experienced the same subjective benefit with both saline and dextran. She felt better and was pleased with both treatments in spite of an obvious progression in her disease. Dysphagia first appeared during dextran infusions and subsided with saline. A modest improvement in one of the complaints of another patient, axillary contractures, coincided with a course of saline infusions. This may ordinarily have been ascribed to the treatment being evaluated.

Low molecular weight dextran is essentially a safe treatment, but acute renal failure (Morgan, Little, and Evans, 1966) and hypersensitivity have been reported; one patient in this study developed hypersensitivity. Furthermore, the treatment is expensive (a course of infusions costs £32) and demanding in hospital bed space, patient attendance, and medical time.

Although the number of patients in this study is small, objective evaluation suggests that no alteration 
in the course of the disease of practical value is likely to be achieved by dextran infusions. Nevertheless, the peripheral circulation is improved in most patients and in a few this may persist for a prolonged period (Holti, 1965). In the occasional patient with disabling ischaemic pain and digital ulceration, who has responded well to an initial infusion of dextran, repeated infusions perhaps during each winter may well be worthwhile, but our experience suggests that the skin and visceral involvement with scleroderma will be unaffected.

\section{Summary}

Six patients with scleroderma of various patterns, duration, and severity have been treated with $\underline{ }$. periodic infusions of low molecular weight dextran under controlled conditions.

Although temporary improvement to the digital circulation may occur, the course of the underlying disease appears to be unchanged.

This treatment may, however, have a place in the

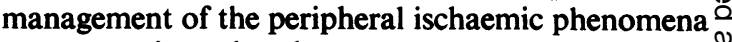
accompanying scleroderma.

\section{REFERENCES}

Bywaters, E. G. L., and Scott, J. T. (1965). In "Progress in Clinical Rheumatology", ed. A. St. J. Dixon, p. 142-143. Churchill, London.

Denis, M. (1967). "Le traitement des sclérodermies par le Rheomacrodex". Thèse pour le Doctorat en Medicine. Faculté de Médecine de Paris.

Gelin, L. E., and Ingelman, B. (1961). Acta chir. scand., 122, 294 (Rheomacrodex-a new dextran solution for rheological treatment of impaired capillary flow).

— and Zederfeldt, B. (1960). Ibid., 119, 168 (Low molecular weight dextran-a rheologic agent counteracting capillary stagnation).

Gregersen, M. L., Peric, B., Usami, S., Chien, S., Chang, C., and Sinclair, D. G. (1963). Fed. Proc., 22, 641 (Studies on blood viscosity at low shear rates: Effects of low and high molecular dextrans).

Gronwall, A. (1957). "Dextran and its use in colloidal infusion solutions". Diss. Stockholm.

Hall, A. P., and Scott, J. T. (1966). Ann. rheum. Dis., 25, 175 (Failure of epsilon-aminocaproic acid in the treatment of scleroderma).

Holti, G. (1965). Brit. J. Derm., 77, 560 (The effect of intermittent low molecular dextran infusions upon digital circulation in systemic sclerosis).

Jefferis, J. E., and Dixon, A. St. J. (1962). Ann. rheum. Dis., 21, 295 (Failure of relaxin in the treatment of scleroderma).

Kantor, I. (1966). Arch. Derm. (Chicago), 94, 675 (Scleroderma treated with dextran 40 (Rheomacrodex) ).

Klein, R., and Harris, S. B. (1955). Amer. J. Med., 19, 798 (Treatment of scleroderma, sclerodactylia and calcinosis by chelation (EDTA) ).

Morgan, T. O., Little, J. M., and Evans, W. A. (1966). Brit. med. J., 2, 737 (Renal failure associated with low-molecular-weight dextran infusion).

Powley, P. H. (1964). Amer. Heart J., 67, 424 (Rheomacrodex in peripheral ischemia).

Ricketts, C. R. (1961). Prog. org. Chem., 5, 73 (The chemistry of dextran).

Rodnan, G. P., Black, R. L., Bollet, A. J., and Bunim, J. J. (1956). Ann. intern. Med., 44, 16 (Observations on the use of prednisone in patients with progressive systemic sclerosis).

Schenk, W. G., Delin, N. A., Domanig, E., Hahnloser, P., and Hoyt, R. K. (1964). Arch. Surg., 89, 783 (Blood viscosity as a determinant of regional blood flow).

Zion, M. M., Goldberg, B., and Suzman, M. M. (1955). Quart. J. Med., 24, 215 (Corticotrophin and cortisone in the treatment of scleroderma).

La faillite des infusions de dextran à poids moléculaire peu élevé dans le traitement de la sclérodermie

\section{RÉSUMÉ}

Six malades atteints de sclérodermie de différents types, de durée et de sévérité variables ont été traités par des infusions périodiques de dextran à poids moléculaire peu élevé sous des conditions contrôlées.

Malgré qu'une amélioration temporaire de la circulation digitale peut avoir lieu, le cours de la maladie même semble inchangé.

Ce traitement peut pourtant avoir une place dans le traitement du phénomène ischémique périphérique accompagnant la sclérodermie. Falla de las infusiones de dextrán de poco peso molecular
en la esclerodermia

SUMARIO

Seis pacientes con esclerodermia de varios tipos $y$ స్ట duración y severidad variables han sido tratados con $\sigma$ infusiones periódicas de dextrán de poco peso molecular en condiciones controladas.

$\mathrm{Si}$ bien pudiera ocurrir mejora temporal en la circu- $\bar{\complement}$ lación digital, el curso de la enfermedad misma parece inalterado. Este tratamiento podría, sin embargo, ser útil en la terapia del fenómeno isquémico periférico que acompaña a la esclerodermia. 